\title{
SHARP FEKETE-SZEGŐ COEFFICIENTS FUNCTIONAL, DISTORTION AND GROWTH INEQUALITIES FOR CERTAIN $p$-VALENT CLOSE-TO-CONVEX FUNCTIONS
}

\author{
SHASHI KANT
}

Abstract. In the present paper certain subclass $\mathscr{K}_{p}^{s}(\phi)$ of $p$-valent close-to-convex functions in the unit disc is defined by means of subordination. Sharp estimates for the Fekete-Szegó functional for functions belonging to the class $\mathscr{K}_{p}^{s}(\phi)$ are obtained. Sharp distortion theorem, growth theorem and a subordination result are also obtained.

Mathematics subject classification (2010): 30C45.

Keywords and phrases: Multivalent function, starlike function, close-to-convex function, Fekete-Szegố functional, distortion and growth theorem, subordination.

\section{REFERENCES}

[1] Y. Abu Muhanna, L. Li and S. Ponnus amy, Extremal problems on the class of convex functions of order -1/2, Arch. Math. (Basel), 103, 6 (2014), 461-471.

[2] R. M. Ali, V. RAVICHANDRAN AND S. K. LEE, Subclasses of multivalent starlike and convex functions, Bull. Belg. Math. Soc. Simon Stevin, 16, (2009), 385-394.

[3] R. M. Ali, V. Ravichandran And N. Seenivas Agan, Coefficient bounds for p-valent functions, Appl. Math. Comput. 187, (2007), 35-46.

[4] M. K. Aouf, R. M. EL-Ashwah And H. M. ZAYed, Fekete-Szegó inequalities for p-valent starlike and convex functions of complex order, J. Egyptian Math. soc. 22, (2014), 190-196.

[5] J. E. BROWN, A. TsAO, On the Zalcman conjecture for starlike and typically real functions, Math. Z. 191, (1986), 467-474.

[6] N. E. Cho, O. S. KWOn And V. Ravichandran, Coefficient, distortion and growth inequalities for certain close-to-convex functions, J. Ineq. Appl. 1, (2011), pp. 7.

[7] M. Fikete AND G. SZEGő, Eine Bemerkung über ungerade schlichte Funktionen, J. London Math. Soc. 8, (1933), 85-89.

[8] C. GAO AND S. ZHOU, On a class of analytic functions related to the starlike functions, Kyungpook Math. J. 45, 1 (2005) 123-130.

[9] F. R. KEOGH AND E. P. MERKES, A coefficient inequality for certain classes of analytic functions, Proc. Amer. Math. Soc. 20, (1969), 8-12.

[10] W. KoEPF, On the Fekete-Szegó problem for close-to-convex functions, Proc. Amer. Math. Soc. 101, 1 (1987), 89-95.

[11] W. KOEPF, On the Fekete-Szegó problem for close-to-convex functions II, Arch. Math. (Basel), 49, 5 (1987), 420-433.

[12] J. KowAlCZYK And E. Les-Bomba, On a subclass of close-to-convex functions, Appl. Math. Lett. 23, (2010), 1147-1151.

[13] S. L. Krushral, Proof of the Zalcman conjecture for initial coefficients, Georgian Math. J. 17, 4 (2010), 663-681.

[14] L. Li And S. Ponnus Amy, On the genralized Zalcman functional $\lambda a_{n}^{2}-a_{2 n-1}$ in the close-to-convex family, Proc. Amer. Math. Soc. 145, 2 (2017), 833-846.

[15] L. Li, S. Ponnus AMY AND J. QIAO, Generalized Zalcman conjecture for convex functions of order $\alpha$, Acta Math. Hungar. 150, 1 (2016), 234-246. 
[16] W. MA, Generalized Zalcman conjecture for starlike and typically real functions, J. Math. Anal. Appl. 234, (1999), 328-339.

[17] W. C. MA AND D. Minda, A unified treatment of some special classes of univalent functions, in Proceedings of the Conference on Complex Analysis, (Tianjin, 1992) Internat. Press, Cambridge, Mass, USA, 1, (1994), 157-169.

[18] T. PANIGRAHI AND R. K. RAInA, Fekete-Szegó coefficient functional for quasi-subordination class, Afr. Mat. 28, 5-6 (2017), 707-716.

[19] J. K. Prajapat AND A. K. Mishra, Certain new subclass of close-to-convex functions, Acta Univ Apulensis Math. Inform. 38, (2014), 263-271.

[20] S. Ruscheweyh And T. SheIL-Small, Hadamard products of schlicht functions and the PolyaSchoenberg conjecture, Comment. Math. Helv. 48, (1973), 119-135.

[21] A. Soni AND S. KAnt, A new subclass of close-to-convex functions with Fekete-szegö problem, J. Rajasthan Acad. Phys. Sci. 12, 2 (2013), 125-138.

[22] B. Seker And N. E. Cho, A subclass of close-to-convex functions, Hacet. J. Math. Stat. 42, 4 (2013), 373-379.

[23] H. M. SRivastava, A. K. Mishra And M. K. Das, The Fekete-Szegó problem for a subclass of close-to-convex functions, Complex Var. Theory Appl. 44, (2001), 145-163.

[24] Z. G. WANG, C. Y. GAO AND S. M. YUAN, On certain new subclass of close-to-convex functions, Matematički Vesnik 58, 3-4 (2006), 119-124.

[25] Q. H. XU, H. M. SRIVASTAVA AND Z. LI, A certain subclass of analytic and close-to-convex functions, Appl. Math. Lett. 24, (2011), 396-401. 